\title{
РЕШЕНИЕ ЗАДАЧ ПРОДОВОЛЬСТВЕННОГО ОБЕСПЕЧЕНИЯ ГОСУДАРСТВА В РОССИЙСКОМ МЕХАНИЗМЕ ПРАВОВОГО РЕГУЛИРОВАНИЯ ТОРГОВЛИ ХЛЕБОМ НА РУБЕЖЕ XIX - XX ВB.
}

Аннотация: В историческом аспекте российской действительности рубежа ХІХ-XX вв. в статье подняты актуальные проблемы, лежащие в сфере обеспечения продовольственной безопасности государства. Изучение архивных документов и анализ нормативно-правовых актов Российской Империи 1881 - 1913 гг. позволили автору выявить специифику отечественного механизма правового регулирования хлебной торговли, направленного на решение задач продовольственного обеспечения государства, а также показать степень вмешательства государства в частные отношения в сфере хлебной торговли в условиях рынка.

Ключевые слова: Юриспруденция, указ, торговля, продовольствие, иена, хлеб, неурожай, запрет, экспорт, пиеница, зерно, рожь

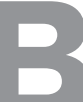
общем торговом балансе России 2-й половины XIX - начала XX вв. ведущая роль принадлежала торговле хлебом. Именно хлебная торговля имела непреходящее значение как основная отрасль российского экспорта и один из главных источников валютных поступлений для экономики страны со средним уровнем развития, обладающей при этом огромными пространствами и многочисленным крестьянским населением.

Но, как известно, основной проблемой сельскохозяйственного производства являются резкие колебания урожайности. На рубеже XIX - XX вв. в хлебородных регионах России они были постоянным явлением. Недороды 1891 г., 1894 г., 1895 г., 1897 1898 гг., 1901 г., 1906 - 1907 гг., 1911 г. нарушали ритм аграрного развития. Уровень же продовольственного обеспечения государства, призванный соответствовать интересам его продовольственной независимости, является одним из важнейших факторов национальной безопасности. Потому в условиях развития рыночных отношений государство в такие периоды активизировало свое вмешательство в сферу торговли этим продуктом первой необходимости.

Ближайшими задачами правительства становились борьба с дороговизной хлеба, а также правильная организация его закупки и перевозки в неурожайные местности. Проблемы в этой сфере, как правило, решались с помощью кредитной, тарифной политики ${ }^{1}$ и административного регулирования.

В соответствии с действовавшим законодательством губернаторы «в интересах народного продовольствия» бдительно надзирали «за свободною и беспрепятственною торговлей хлебом и другими жизненными припасами», ${ }^{2}$ а также принимали меры против «перекупа» этих товаров и непомерного повышения цен. Устав об обеспечении народного продовольствия Свода законов Российской империи (ст. 127) возлагал на органы городского самоуправления в случае действительной необходимости «в отвращение произвольного возвышения цен на нужнейшие предметы продовольствия, а именно, на печеный хлеб и на мясо», установление таксы цен, утверждаемых губернаторами или градоначальниками. Таксы формировались на основании сведений о ценах, периодически собираемых городскими и земскими управами (ст. 100 - 110). Органы городского самоуправления и полиция должны были наблюдать

\footnotetext{
${ }^{1}$ Таможенная и тарифная политика Правительства в области хлебной торговли нашла подробное освящение в монографии Т. М. Китаниной. См.: Китанина Т. М. Хлебная торговля России в конце XIX - начале XX века. Стратегия выживания, модернизационные процессы, правительственная политика. СПб.: «ДМИТРИЙ БУЛАНИН», 2011. - 608 с.

2 Лексис В. Торговля. Ч. ІІ. Рига, 1914. С. 129.
} 


\section{Национальная безопасность 2(25) • 2013}

за тем, чтобы предметы продовольствия, на которые установлена такса, продавались по цене «не свыше оной и на указанный вес» (ст. 129). ${ }^{3}$ Для обеспечения пищевыми продуктами городского населения Устав об обеспечении народного продовольствия обязывал городские общественные управления озаботится назначением базарных дней и поощрением сельских жителей к привозу на такие базары сельскохозяйственных продуктов для продажи их по вольной цене и без уплаты особых сборов. Такая торговля могла производиться с возов, лодок, но без устройства лавок или шалашей (ст. $119-120){ }^{4}$

Из числа мер поддержки торгово-промышленных предприятий вообще и производителей хлеба в особенности Министерство Финансов обратило внимание на расширение выдачи ссуд, обеспечиваемых товарами. С 1885 г. выдача ссуд под хлеб в зерне была организована конторами Государственного банка. ${ }^{5}$ В 1888 г. Государственному Банку законом было временно (в течение трех лет) разрешено производить при посредстве железных дорог выдачу ссуд под залог хлебных грузов, а железным дорогам, сверх участия в ссудной операции, предоставлено право принимать заложенный хлеб на хранение в своих складах и продавать его по поручению собственников. ${ }^{6}$ Через полгода, по представлению И. А. Вышнеградского, самим железным дорогам было разрешено выдавать ссуды под хлебные грузы из эксплутационных средств или при посредничестве частных банков. ${ }^{7}$ В дальнейшем действие этих положений неоднократно продле-

\footnotetext{
${ }^{3}$ Свод законов Российской империи. Все 16 томов со всеми относящимися к ним продолжениями в одной книге. Под ред. Ф. Волкова, Ю. Д. Филиппова. СПб., 1900. Т. ХІІІ. (Издание 1892 г.). Устав об обеспечении Народного Продовольствия. C. 11 .

${ }^{4}$ Там же. С. 10.

${ }^{5}$ Министерство Финансов 1802 - 1902 г. Ч. ІІ. СПб., 1902. C. 238 .

${ }^{6}$ Полное собрание законов Российской империи. Собрание третье (ПС3 - III). T. VIII. № 5348. Высочайше утвержденное мнение Государственного Совета от 14 июня 1888 г. «О предоставлении Государственному Банку производить временно, при посредстве железных дорог, выдачу ссуд под залог хлебных грузов». С. $394-396$.

${ }^{7}$ ПС 3 - III. Т. IX. № 5727. Высочайше утвержденное мнение Государственного Совета от 24 января 1889 г. «О разрешении железным дорогам выдавать ссуды под хлебные грузы из эксплуатационных средств или при посредстве частных банков». С. 34.
}

валось. ${ }^{8}$ В 1893 г. государство провело ряд дополнительных мероприятий, поощрявших торговлю хлебом: была облегчена выдача ссуд под хлеб из Государственного Банка как непосредственно, так и при посредничестве земств, железных дорог и частных банков; значительно понижены железнодорожные тарифы по перевозке хлебных грузов в некоторых направлениях; усилены закупки ржи для нужд военного ведомства и т. д. ${ }^{9}$

Даже в период неурожайных лет при этом сохранялся довольно интенсивный вывоз зерна, который в отдельные моменты сочетался с усиленным его ввозом. Многочисленная армия коммерсантов вытягивала, как насосом, у производителя все его зерно. В таких условиях неурожай 1891 г., а затем 1897 г. превращался для многих местностей «в голод». ${ }^{10}$ Эти обстоятельства вынуждали правительство переходить к более решительным действиям, связанным с прямым вмешательством в частные торговые отношения, используя законодательные механизмы.

К исключительным мерам прибегли в 1891 г., когда неурожай посетил самую хлебородную полосу России, затронув 17 губерний: Воронежскую, Вятскую, Казанскую, Курскую, Нижегородскую, Оренбургскую, Орловскую, Пензенскую, Пермскую, Рязанскую, Самарскую, Саратовскую, Симбирскую, Тамбовскую, Тобольскую, Тульскую и Уфимскую.

Именным Высочайшим указом, данным Сенату 28 июля 1891 г., ввиду неурожая и произошедшего вследствие этого быстрого возвышения цен на рожь и корма, «отпуск за границу из портов Балтийского, Черного и Азовского морей и по Западной сухопутной границе ржи в зерне, ржаной муки и отрубей всякого рода с 15 Августа сего 1891 года» ${ }^{11}$ был за-

\footnotetext{
${ }^{8}$ ПС3 - III. Т. ХІ. № 7813. Высочайше утвержденное мнение Государственного Совета от 11 июня 1891 г. «О продлении срока действия Правил о разрешении Государственному Банку и железным дорогам выдавать ссуды под хлебные грузы». С. 386 - 387; ПСЗ - III. T. XIV. № 10770. Высочайше утвержденное мнение Государственного Совета от 6 июня 1894 г. «О продлении действия правил о выдаче Государственным Банком при посредстве железных дорог ссуд под хлебные грузы, а также о выдаче таких ссуд железными дорогами из эксплуатационных средств или при посредстве частных банков». С. 432.

${ }^{9}$ Министерство Финансов 1802 - 1902 г. Ч. ІІ. СПб., 1902. С. 238.

${ }^{10}$ Лященко П. И. Хлебная торговля на внутренних рынках Европейской России. Описательно-статистическое исследование. СПб. 1912. С. 3.

${ }^{11}$ ПС3 - III. Т. XI. № 7939. Именной Высочайший указ, данный Сенату 28 июля 1891 г. «О воспрещении отпуска за границу ржи в зерне, ржаной муки и отрубей всякого рода». С. 545 - 546.
} 
прещен. 1 сентября такой запрет был распространен и на порты Архангельской губернии. ${ }^{12}$ Кроме того, по распоряжению Министра Финансов были снижены железнодорожные тарифы на перевозку хлеба в пострадавшие от неурожая местности. 29 августа того же года Именным Высочайшим указом, данным Сенату, был запрещен вывоз пшеницы из Закаспийской области в Персию. ${ }^{13}$ 16 октября запрет вывоза за границу был наложен на все виды зернового хлеба (кроме пшеницы) и картофель, а равно «на приготовляемые из запрещенных к вывозу зерновых хлебов и картофеля: муку, солод и крупу, тесто и печеный хлеб». ${ }^{14}$ Наконец, Указом от 3 ноября 1891 г. $^{15}$ был запрещен и вывоз пшеницы, а также приготовляемых из нее пищевых продуктов. ${ }^{16}$

Таким образом, осенью 1891 г. был наложен полный запрет на вывоз из России хлеба, сначала ржи, а затем и пшеницы. По объяснению Министра Финансов А. А. Абазы, мотивом этого запрещения было «не опасение, что хлеба в России не хватит, а стремление предотвратить усиленный отлив хлеба в Западную Европу, где цена стояла в то время выше, чем у нас, при слабой у нас вообще покупной способности крестьянского населения; затем обратное привлечение хлеба в Россию происходило бы уже по чрезмерно высоким ценам». ${ }^{17}$ При этом внутри России Комитет Министров счел необходимым сохранить полную свободу хлебной торговли.

\footnotetext{
${ }^{12}$ ПС3 - III. Т. ХІ. № 7963. Именной Высочайший указ, данный Сенату 1 сентября 1891 г. «О воспрещении отпуска за границу из портов Архангельской губернии ржи, ржаной муки и отрубей». С. 556.

${ }^{13}$ ПС3 - III. Т. ХІ. № 7954. Именной Высочайший указ, данный Сенату 29 августа 1891 г. «О воспрещении вывоза пшеницы из Закаспийской области в Персию». С. 552 - 553.

${ }^{14}$ ПС3 - III. Т. ХІ. № 8010. Именной Высочайший указ, данный Сенату 16 октября 1891 г. «О распространении воспрещения отпуска за границу ржи, ржаной муки и отрубей всяких на все прочие, кроме пшеницы, зерновые хлеба и картофель, а равно на приготовляемые из запрещенных к вывозу зерновых хлебов и картофеля: муку, солод и крупу, тесто и печеный хлеб». С. $573-574$.

15 ПСЗ - III. Т. ХІ. № 8037. Именной Высочайший указ, данный Сенату 3 ноября 1891 г. «О воспрещении отпуска за границу пшеницы и приготовляемых из нее пищевых продуктов». С. $589-590$.

16 Указ был введен в действие уже на следующий день после его официального обнародования, т. е. с 10 ноября.

${ }^{17}$ Исторический обзор деятельности Комитета Министров в пяти томах. T. IV. СПб.,1902. С. 136.
}

В начале 1892 г. Александр III издал два указа, предусматривающие некоторые исключения из общего запрета, но не изменяющие в целом сути продовольственной политики, связанной с приостановкой экспорта хлебной продукции.

В изъятие положений Указа от 1 сентября 1891 г. «О воспрещении отпуска за границу из портов Архангельской губернии ржи, ржаной муки и отрубей», в начале февраля было признано возможным допустить с целью «сохранения меновых торговых сношений поморов Северного края с Норвегией» ${ }^{18}$ вывоз хлеба из портов Архангельской губернии в Норвегию в количестве не свыше двухсот тысяч пудов. Такой вывоз должен был отвечать следующим условиям: 1) разрешаться только поморам Архангельской губернии, производящим меновую торговлю с Норвегией на русских судах; 2) к вывозу допускать только хлеб, предназначенный исключительно «для промена в норвежских портах на рыбу, а не для продажи»; 3) вывоз должен был проводиться под контролем, осуществляемым на основании правил, установленных по взаимному соглашению Министров Иностранных, Внутренних Дел и Финансов. На деяния, связанные с нарушением этих правил, Указ распространял наказания, предусмотренные «за незаконную, тайно от таможенных властей, погрузку и вывоз из России запрещенных к отпуску за границу товаров», т. е. за деяния, содержащиеся в ст.ст. 1083 и 1551 Устава Таможенного, т. VI Свода законов Российской империи. ${ }^{19}$

В изъятие из установленного Высочайшим указом от 3 ноября 1891 г. запрета на отпуск за границу приготовляемых из пшеницы пищевых продуктов, Указом Александра III был разрешен вывоз из Черноморских и Азовских портов пшеничной муки, при условии ввоза в Россию пшеницы в зерне в количестве, по весу равном допускаемой к вывозу муке. ${ }^{20}$

Результаты урожая 1892 г. позволили правительству постепенно снять запрет на экспорт хлеба. Указом Императора от 4 июня 1892 г. был разрешен вывоз «как морем, так и по сухопутной границе,

\footnotetext{
${ }^{18}$ ПС3 - III. Т. ХІІ. № 8316. Именной Высочайший указ, данный Сенату 7 февраля 1892 г. «О разрешении вывоза хлеба из портов Архангельской губернии в Норвегию». С. 90 - 91.

19 Там же.

${ }^{20}$ ПС3 - III. Т. XII. № 8411. Именной Высочайший указ, данный Сенату 13 марта 1892 г. «О дозволении вывоза за границу из Черноморских и Азовских портов пшеничной муки, при условии ввоза в Россию пшеницы в зерне, в равном по весу количестве». С. 159.
} 


\section{Национальная безопасность 2(25) • 2013}

хлебов и хлебных продуктов, за исключением ржи, ржаной муки и отрубей всякого рода», ${ }^{21}$ а 7 августа - и этих продуктов. ${ }^{22} 30$ августа последовала отмена запрета на отпуск пшеницы из Закаспийской области в Персию. ${ }^{23}$

Таким образом, в конце XIX - начале XX веков как предприниматели, так и государственные деятели воспринимали возможность ограничения, а тем более запрещения, вывоза хлеба за рубеж как крайние меры. К подобным мерам, связанным с прямым вмешательством в частные торговые отношения, государство прибегало лишь в исключительных случаях, связанных с защитой интересов национальной продовольственной безопасности. Неурожай 1891 г. и последовавший за ним голод явились теми условиями, которые вызвали необходимость таких экстренных законодательных мер чрезвычайного характера. Однако сразу же после сбора нового урожая, позволившего снять остроту хлебного дефицита, введенные правительством ограничения на экспорт хлеба были отменены. При этом внутри России свобода хлебной торговли полностью сохранялась.

Тем временем существовавшие проблемы организации хлебной торговли (обеспечения качества товарного хлеба; устранения недостатка элеваторов и зернохранилищ, затруднявшего ссудные под хлеб операции; сокращения числа посредников, наживавшихся на спекуляции хлебом, а также ограничения их произвола; формирования государственных резервов зерна) и перманентно возникавшие трудности реализации собранного урожая на сколько-нибудь выгодных для непосредственного производителя условиях порождали самые «смелые» законодательные предложения, вносившиеся в Государственную Думу III и IV созывов. Так 13 марта 1912 г. в Государственную Думу за подписью 82 членов был внесен законопроект, предполагавший введение правительственной монополии на вывоз хлеба за границу и установление цен на хлеб «законодательными учреждениями». ${ }^{24} \mathrm{~A}$

\footnotetext{
${ }^{21}$ ПС3 - III. Т. ХІІ. № 8663. Именной Высочайший указ, данный Сенату 4 июня 1892 г. «О разрешении вывоза как морем, так и по сухопутной границе, хлебов и хлебных продуктов, за исключением ржи, ржаной муки и отрубей всякого рода». С. 395.

${ }^{22}$ ПС3 - III. Т. ХІІ. № 8886. Именной Высочайший указ, данный Сенату 7 августа 1892 г. «О разрешении отпуска за границу ржи в зерне, ржаной муки и отрубей всякого рода». С. 558.

${ }^{23}$ ПС3 - III. Т. XII. № 8909. Именной Высочайший указ, данный Сенату 30 августа 1892 г. «Об отмене воспрещения отпуска пшеницы из Закаспийской области в Персию». С. 567.

${ }^{24}$ Текст законодательного предположения 82-х «О мерах к
}

через год, 13 марта 1913 г., последовал новый законопроект за подписью 37 членов, объявлявший хлебную торговлю исключительной регалией государства и предлагавший распространить государственную монополию не только на внешнюю, но и на внутреннюю торговлю хлебом. ${ }^{25}$

Но в России рубежа XIX - XX вв., где реализация урожая являлась подведением итогов годичной деятельности $80 \%$ населения, непосредственно занятого сельскохозяйственным промыслом, и отражалась на всей промышленной и торговой жизни, монополизация государством внутренней хлебной торговли была бы равносильна учреждению правительственной опеки над всем частным хозяйством в стране. Государство не просто не было готово к многомиллиардным денежным вложениям, необходимым для грамотной реализации подобных законопроектов, ${ }^{26}$ и взятию на себя всех финансовых рисков сельскохозяйственного производства. Это противоречило бы основным принципам буржуазных отношений, связанным со свободой предпринимательства и защитой прав собственников, и было возможно только в результате коренной ломки всего общественно-экономического уклада. Потому подобные предложения в правительственных кругах были признаны утопическими, а значит - неприемлемыми. ${ }^{27}$

Цели же, которые преследовали «авторы законодательного предположения «о хлебной торговле» - упорядочить как внешнюю, так и внутреннюю торговлю хлебом, оказать в благоприятном смысле влияние на хлебные цены и удержать производителей зерновых продуктов от несвоевременной и поспешной реализации

упорядочению хлебной торговли» см.: Промышленность и Торговля в законодательных учреждениях 1907 - 1912 гг. Доклад Совета Съездов Представителей Промышленности и Торговли VI Очередному Съезду. СПб., 1912. С. 332 - 333; Российский государственный исторический архив (РГИА). Фонд 1276 (Совет Министров (1905 - 1917)). Оп. 8. Д. 125 б. Л. 2 - 10.

${ }^{25}$ РГИА. Ф. 1276. Оп. 8. Д. 125 б. Л. $41-42$.

${ }^{26}$ По приблизительным подсчетам Министерства Финансов, при хлебном экспорте, достигающем 500 - 750 млн. рублей, потребовались бы еще более крупные оборотные капиталы. Только на постройку элеваторов государству необходимо было бы потратить около 730.000.000 рублей. К тому же огромные расходы были бы ежегодно необходимы на их содержание и обслуживание. РГИА. Ф. 1276. Оп. 8. Д. 125 б. Л. 71 об - 73. Приложение к письму Товарища Министра Финансов, тайного советника Вебера на имя Управляющего делами Совета Министров действительного статского советника Плеве от 22 апреля 1913 г. за № 3426.

${ }^{27}$ РГИА. Ф. 1276. Оп. 8. Д. 125 б. Л. 77. 
хлебного урожая», по мнению Министерства Финансов, могли быть достигнуты «не установлением государственной хлебной монополии, а путем, с одной стороны, создания сети станционных, распределительных и портовых зернохранилищ и планомерной их эксплуатации распоряжением Правительства и, с другой, - путем постепенного привлечения к созданию сети мелких зернохранилищ всего сельского населения России через посредство учреждений мелкого кредита». ${ }^{28}$

Именно в этом направлении Правительство активизировало свою деятельность в начале 2 -го десятилетия XX века. ${ }^{29}$ Расширение сети элеваторов средствами Государственного Банка в начале второго десятилетия XX в. прокладывало путь усиления государственного вмешательства в область хлебной торговли, дающий дополнительные возможности для решения важнейших задач:

1) продовольственного обеспечения государства, формирования государственных фондов и государственных резервов зерна для внутреннего потребления на случай неурожая; а также

2) улучшения качества товарного хлеба;

3) упорядочения его хранения и торговли;

4) упрощения ссудной под хлеб операции;

5) сокращения числа посредников, наживавшихся на спекуляции хлебом, а также ограничения их произвола;

6) сбалансирования цен, приемлемых и для производителей, и для потребителей этого важнейшего продукта первой необходимости.

\section{Библиография:}

1. Российский государственный исторический архив (РГИА). Фонд 1276 (Совет Министров (1905 - 1917)). Оп. 8. Д. 125 б.

2. Полное собрание законов Российской империи. Собрание третье (ПСЗ - III). T. VIII. № 5348. Высочайше утвержденное мнение Государственного Совета от 14 июня 1888 г. «О предоставлении Государственному Банку производить временно, при посредстве железных дорог, выдачу ссуд под залог хлебных грузов». С. $394-396$.

\footnotetext{
${ }^{28}$ Там же. Л. 74 об.

${ }^{29}$ Подробнее о правовом регулировании отношений в сфере учреждения и деятельности товарных складов см.: Жолобова Г. А. Правовое регулирование торгово-промышленных отношений в пореформенной России 1881 - 1913 годов. М, 2007. C. $212-228$.
}

3. ПС3 - III. Т. IX. № 5727. Высочайше утвержденное мнение Государственного Совета от 24 января 1889 г. «О разрешении железным дорогам выдавать ссуды под хлебные грузы из эксплоатационных средств или при посредстве частных банков». С. 34.

4. ПСЗ - III. Т. ХІ. № 7813. Высочайше утвержденное мнение Государственного Совета от 11 июня 1891 г. «О продлении срока действия Правил о разрешении Государственному Банку и железным дорогам выдавать ссуды под хлебные грузы». С. $386-387$.

5. ПСЗ - III. Т. ХІ. № 7939. Именной Высочайший указ, данный Сенату 28 июля 1891 г. «О воспрещении отпуска за границу ржи в зерне, ржаной муки и отрубей всякого рода». С. $545-546$.

6. ПСЗ - III. Т. ХІ. № 7954. Именной Высочайший указ, данный Сенату 29 августа 1891 г. «О воспрещении вывоза пшеницы из Закаспийской области в Персию». С. $552-553$.

7. ПСЗ - III. Т. ХІ. № 7963. Именной Высочайший указ, данный Сенату 1 сентября 1891 г. «О воспрещении отпуска за границу из портов Архангельской губернии ржи, ржаной муки и отрубей». С. 556.

8. ПСЗ - III. Т. ХІ. № 8010. Именной Высочайший указ, данный Сенату 16 октября 1891 г. «О распространении воспрещения отпуска за границу ржи, ржаной муки и отрубей всяких на все прочие, кроме пшеницы, зерновые хлеба и картофель, а равно на приготовляемые из запрещенных к вывозу зерновых хлебов и картофеля: муку, солод и крупу, тесто и печеный хлеб». C. $573-574$.

9. ПСЗ - III. Т. ХІ. № 8037. Именной Высочайший указ, данный Сенату 3 ноября 1891 г. «О воспрещении отпуска за границу пшеницы и приготовляемых из нее пищевых продуктов». С. 589-590.

10. ПСЗ - III. Т. XII. № 8316. Именной Высочайший указ, данный Сенату 7 февраля 1892 г. «О разрешении вывоза хлеба из портов Архангельской губернии в Норвегию». С. 90 - 91.

11. ПС3 - III. Т. XII. № 8411. Именной Высочайший указ, данный Сенату 13 марта 1892 г. «О дозволении вывоза за границу из Черноморских и Азовских портов пшеничной муки, при условии ввоза в Россию пшеницы в зерне, в равном по весу количестве». С. 159.

12. ПСЗ - III. Т. ХІІ. № 8663. Именной Высочайший указ, данный 


\section{Национальная безопасность 2(25) • 2013}

13. Китанина Т. М. Хлебная торговля России в конце XIX - начале XX века. Стратегия выживания, модернизационные процессы, правительственная политика. СПб.: «ДМИТРИЙ БУЛАНИН», 2011. - 608 с.

14. Лексис В. Торговля. Ч. ІІ. Рига, 1914. С. 129.

15. Лященко П. И. Хлебная торговля на внутренних рынках Европейской России. Описательностатистическое исследование. СПб. 1912. С. 3.

16. Министерство Финансов 1802 - 1902 г. Ч. II. СПб., 1902. С. 238.

17. Промышленность и Торговля в законодательных учреждениях 1907-1912 гг. Доклад Совета Съездов Представителей Промышленности и Торговли VI Очередному Съезду. СПб., 1912. С. 332 - 333.

\section{References (transliteration):}

1. Zholobova G. A. Pravovoe regulirovanie torgovopromyshlennykh otnosheniy v poreformennoy Rossii 1881 - 1913 godov. M, 2007. S. $212-228$.

2. Kitanina T. M. Khlebnaya torgovlya Rossii v kontse XIX - nachale XX veka. Strategiya vyzhivaniya, modernizatsionnye protsessy, pravitel'stvennaya politika. SPb.: «DMITRIY BULANIN», 2011. $608 \mathrm{~s}$.

3. Leksis V. Torgovlya. Ch. II. Riga, 1914. S. 129.

4. Lyashchenko P. I. Khlebnaya torgovlya na vnutrennikh rynkakh Evropeyskoy Rossii. Opisatel'nostatisticheskoe issledovanie. SPb. 1912. S. 3. 